\title{
Effects of poly-sal polymer and barite addition on rheological properties of algerian bentonite
}

ILYES BACHIR BELMEHDI - Laboratory of Petroleum Equipment's Reliability and Materials, Faculty of Hydrocarbons and Chemistry, University M'Hamed Bougara of Boumerdes, Algeria

AbderRahmane MELLAK - Laboratory of Hydrocarbons Physical Engineering, Faculty of Hydrocarbons and Chemistry, University of M'Hamed Bougara Boumerdes, Algeriat - a.mellak@univ-umbb.dz

LARBI HAMMADI - Laboratory of Rheology, Transport and Treatment of the Complex Fluids, University of Science and Technology, Mohamed Boudiaf Oran, Algeria

Érkezett: 2020. 04. 17. - Received: 17. 04. 2020. - https://doi.org/10.14382/epitoanyag-jsbcm.2021.1

\section{Abstract}

In this paper, we investigate the effect of Poly-Sal polymer and barite on the rheological properties of bentonite of Maghnia (western Algeria). The modified Cross model is used to fit the stationary flow curves of bentonite at different concentrations of Poly-Sal add in base bentonite (4\%) and the generalized model of Kelvin-Voigt is successfully applied to fit the creep and recovery data and to analyze the viscoelastic properties of the mixture Bentonite-Barite. Finally, the thixotropic behavior studied of the mixture Bentonite-Barite at constant temperature is analyzed by using a structura kinetic model (SKM) in order to account for the time dependent effect. It is demonstrated that the increase in quantity of barite in base bentonite induces a restructuring and reorganization of the particles of the bentonite at the microstructural level.

Keywords: bentonite, barite, Poly-Sal, structural parameter, thixotropy, viscoelasticity
Ilyes BACHIR BELMEHDI

He is petroleum Engineer. Preparing the Phd thesis on the rheology of clay-polymer systems, at the Faculty of Hydrocarbons and Chemistry, M'Hamed Bougara University of Boumerdes, Algeria.

Abderrahmane MELLAK He is the Director of the Hydrocarbon Physics Engineering Laboratory (LGPH) at the Faculty of Hydrocarbons and Chemistry of the University of Boumerdès in Algeria. He is a Research Professor and his research focuses mainly on energy, the rheology of complex fluids, oil and gas drilling, materials, as well as the environment. He is Director of several doctoral theses including the thesis of llyes Bachir Belmahdi.

Larbi HAMMADI He is Doctor of Science in Hydraulics (University of Science and Technology of Oran) and Engineer in Mechanical Engineering. Since 2002, he is Researcher Professor at the University of Science and Technology of Oran (USTOMB) where he exercised many teaching activities. He is actually the director of Laboratory of Rheology, Transport and Complex Fluids Treatment (LRTTFC) Oran Algeria.

\section{Introduction}

The Bentonite represents an important clay material for a multitude of processes and industrial applications due to the exceptional properties of its dispersion in water [1] and their significant influences on the drilling process of oil and gas wells [2-3]. They are found, in particular, as a texturing agent, in cosmetics, as drilling muds in the petroleum industry [45-6] or as a sealant in civil engineering [7-8]. The bentonite is also employed as a thickener in waterproofing of hydraulic structures (dams, large reservoirs, etc...). They are also used for stabilization of the oil-water emulsions [9-10-11].

Despite their potential usefulness, applications of bentonite have been limited because of some reasons, namely their swelling [12] and evolution with time. In order to widen the use of bentonite and improve their sorption properties many additives have been added in bentonite such the electrolytes, polymers [13-14] and barite [15-16].

In addition, the knowledge of the rheological properties of bentonite suspension and bentonite additives is important in industry applications in order to provide information for design and process evaluation, control, storage stability and the degree of bentonite-additive interactions. It is noted that the rheological behavior of bentonite dispersions depends on different factors such as the type and concentration of bentonite, the size of bentonite particles, the $\mathrm{pH}$ and the concentration of the additives in dispersions.

The effect of sodium carboxymethylcellulose, xanthan gum and sodium dodecyl sulfate on rheological proprieties of bentonite was studied [17]. It was shown; for the three additives; that the apparent viscosities of the solutions increase with increasing concentrations. Other authors [18], has investigated the effect of polyethylene Oxide (PEO) and shear rate on rheological properties of bentonite suspensions. The authors demonstrated that when polyethylene oxide (PEO) was added to bentonite clay, the yield stress and fluid consistency index of the mixture increased. The effect of the temperature on the rheological properties of a complex bentonite-sodium carboxymethylcellulose was investigated [19]. They observed that in the liquid like regime the viscosity of the fluids decreased as the temperature increased, and in the solid-like regime, they observed; at low shear stresses; the Brownian effect dominates the hydrodynamic one. An increase of temperature generates an increase of the Brownian motion. Recently, the effect of Hydroxyethyl cellulose on rheological proprieties of Algerian bentonite was studied [20]. A significant increase in the rheological properties of the mixture bentonite-HEC with the increase in HEC concentration has been shown. The impact of barite on structural recovery behavior of bentonite was studied [15]. It has been clearly demonstrated that the structural recovery of mixture bentonite-barite is time-dependent and their yield stress increases with time of rest and quantity of barite add in bentonite. The authors also used the Leong and Nguyen-Boger models in order to model the structural recovery behavior of barite-loaded bentonite suspensions. The impact of barite and ilmenite mixture on enhancing the drilling muds has been investigated [21]. The study showed that the rheological properties of barite/ilmenite mixture give comparable results as barite and has the potential to be used as alternative weighting material especially in a heavier drilling mud.

From the literature different rheological properties of the mixtures bentonite-sodium carboxymethylcellulose, bentonite-xanthan gum, bentonite- polyethylenean Oxide and bentonite- Hydroxyethyl cellulose have been investigated and analyzed by various models $[18,20,22-25]$. However, as far as 
we know only a few studies focused on the rheological behavior of bentonite-barite but no study done on rheological behavior of the mixture bentonite-Poly-sal. Although this polymer is designed to reduce the fluid losses and can be used in drilling fluids to increase the viscosity. For this reason the knowledge of the rheological characteristics of the mixtures bentonite-Polysal polymer and bentonite-barite plays a fundamental role in flows and performance of transport technologies such as losses of linear and singular energy, non-flow zones, recirculation time, and operation of drilling fluids.

The objective of this paper is, mainly, to study the effect of Poly-sal polymer on the rheological properties of a bentonite in a steady state and on the other hand to study the effect of barite on the viscoelastic and thixotropic properties of bentonite. In order to provide useful information for the proper design of pipes and the selection of pumps during use of bentonite-Poly-sal and bentonite-barite in drilling fluids or in others application.

\section{Theoretical time dependent modeling}

In order to model the structural evaluation of the bentonitebarite, we applied the structural kinetic model (SKM) [26], which has been successfully employed for starch pastes and concentrated suspensions of minerals. In this study, the kinetic structural approach assumes that the change in the rheological behavior is associated with shear-induced breakdown of the internal structure in the bentonite-barite system.

The structured state of the thixotropic structure at any time $t$ and under an applied shear rate can be represented by the structural parameter $(\lambda)$ :

$\lambda=\lambda(t, \dot{\gamma})$

Which $\lambda(t, \dot{\gamma})$ is defined as:

$\lambda(t, \dot{\gamma})=\frac{\eta-\eta_{e}}{\eta_{0}-\eta_{e}}$

Where $\eta_{0}$ is the initial apparent viscosity at $\mathrm{t}=0$ (structured state), and $\eta_{\mathrm{e}}$ is the equilibrium apparent viscosity as $\mathrm{t} \rightarrow \infty$ (non-structured state). Note that, both $\eta_{0}$ and $\eta_{\mathrm{e}}$ are functions of the applied shear rate only [27]. The structural parameter $\lambda$ ranged from an initial value of unity for zero shear time to an equilibrium $\lambda_{e}$ valuelower than the unity. The rate of structural breakdown can be expressed as:

$-\frac{d \lambda}{d t}=k\left(\lambda-\lambda_{e}\right)^{n}$

Where $k=k(\dot{\gamma})$ is the rate constant and is the order of the structure breakdown reaction. At a constant applied shear rate, integration of ( 3 ) from $t=0$ to $t$ yields:

$\left(\lambda-\lambda_{e}\right)^{1-n}=(n-1) k t+\left(\lambda_{0}-\lambda_{e}\right)^{1-n}$

Substituting (2) into (4) yields for a constant shear rate:

$\left(\frac{\eta-\eta_{e}}{\eta_{0}-\eta_{e}}\right)^{1-n}=(n-1) k t+1$

\section{Materials and methods}

\subsection{Materials and sample preparation}

\subsubsection{Materials}

The polymer used in this work is the Poly-sal, it's designed to provide filtration control in all types of water-based drilling fluids. This non-ionic, natural polymer is effective in all makeup waters, including high salinity and high hardness brines such as $\mathrm{NaCl}, \mathrm{KCl}, \mathrm{MgCl}_{2}, \mathrm{CaCl}_{2}$ and complex brines. The Polysal polymer used in this work was supplied from Company Algeria. The Table 1 presented the physical properties of the Poly-sal used in this study.

\begin{tabular}{cc} 
Physical appearance & Tan granular powder \\
Specific gravity & 1.5 \\
\hline $\mathrm{pH}$ & 7.0 \\
\hline Solubility in water & Soluble \\
\hline Bulk density & $561 \mathrm{~kg} / \mathrm{m}^{3}$ \\
Table 1 & Typical physical properties of the Poly-sal used in this study \\
1. táblázat & A tanulmányban használt Poly-sal fizikai tulajdonságai
\end{tabular}

The clay used in this study is the bentonite of Maghnia (west of Algeria). The main components of this bentonite sample are: $\mathrm{SiO}_{2}(61.78 \%), \mathrm{Al}_{2} \mathrm{O}_{3}(17.15 \%), \mathrm{Fe}_{2} \mathrm{O}_{3}(3,82 \%)$, $\mathrm{MgO}$ (3.56\%), $\mathrm{CaO}(0.26 \%)$. The specific surface of bentonite and barite used in this study are $1.05 \mathrm{~m}^{2} / \mathrm{g}$ and $2.84 \mathrm{~m}^{2} / \mathrm{g}$ respectively. Fig. 1 shows the particle size distribution of bentonite and barite suspensions measured by the light scattering technique with a Malvern Instruments Mastersizer 2000 system. In order to avoid the formation of aggregates during the measurements, the sample was submitted to ultrasound excitation. We observed in Fig. 1 the particle sizes of bentonite ranging between 1 and $138 \mu \mathrm{m}$ were found with a symmetric distribution centered at about $46 \mu \mathrm{m}$ and particle sizes of barite ranging between 1 and $138 \mu \mathrm{m}$ were found with a symmetric distribution centered at about $25 \mu \mathrm{m}$. We also observed that the maximum volume of bentonite is greater than the maximum volume of barite which means that the bentonite is more swelling compared to barite.

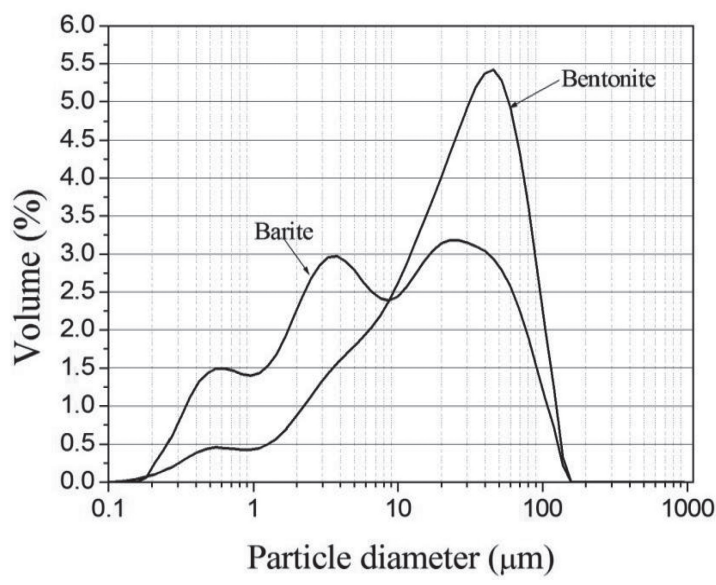

Fig. 1 Particle size distribution of bentonite and barite

1. ábra A bentonit és barit szemcseméret eloszlása 


\subsubsection{Sample preparation}

Given that the way of preparation has a great influence on the final state of suspensions, thus on the rheological behavior, all tests were carefully carried out under equal conditions to allow for comparison of the results.

\subsubsection{Effect of Poly-sal}

For each mixture, the base bentonite suspension has the same mass concentration ( $4 \mathrm{wt} \%$ ). The bentonite powder was dispersed in the required amount of distilled water without any chemical additives. The homogenization was performed under continuous magnetic agitation for 24 hours. The additives at different concentrations $(0.2 ; 0.4 ; 0.6 ; 0.8$ and 1 wt $\%)$ were then added to the base suspensions, afterwards, the mixtures obtained were subjected to a continuous agitation for 24 hours. An average $\mathrm{pH}$ ranging between 9.6 and 11.5 was measured.

\subsubsection{The effect of barite}

The mixture bentonite-barite used in this study contain in proportion by weight $0,1,2,3$ and $4 \mathrm{~g}$ barite to bentonite. The based bentonite mixture consists of $4 \%$ wt solid (i.e. $4 \mathrm{~g}$ bentonite and $96 \mathrm{~g}$ water). In the preparation of the mixture with 1 ratio of barite to bentonite, the mixture compositions consist of $96 \mathrm{~g}$ water, $4 \mathrm{~g}$ bentonite and $4 \mathrm{~g}$ barite. For the 0.75 barite to bentonite ratio the composition is $96 \mathrm{~g}$ water, $4 \mathrm{~g}$ bentonite and $3 \mathrm{~g}$ barite. For the 0.5 ratio, the composition is $4 \mathrm{~g}$ bentonite, $2 \mathrm{~g}$ barite and $96 \mathrm{~g}$ water. For the 0.25 ratio, the composition is $4 \mathrm{~g}$ bentonite, $1 \mathrm{~g}$ barite and $96 \mathrm{~g}$ water. For the 0 ratio the composition is $4 \mathrm{~g}$ bentonite, $0 \mathrm{~g}$ barite and $96 \mathrm{~g}$ water.

\subsection{Experimental set up}

The rheological measurements were performed by using a torque controlled Rhéometer (RS600 from Thermo-Fischer), equipped with a cone-plate geometry (diameter: $60 \mathrm{~mm}$; angle: $2^{\circ}$; gap: $105 \mu \mathrm{m}$ ). It has a Peltier temperature control system that allows having a very quick response to any change in temperature. In order to prevent changes in composition during measurements due to water evaporation, a solvent trap was placed around the measuring device.

\subsubsection{Experimental methods}

\subsubsection{Steady shear measurements}

For study the effect of Poly-sal on the flow properties of bentonite, the sample was pre-sheared at a frequency of $500 \mathrm{~s}^{-1}$ for 60 seconds in the measuring device in order to avoid any memory effect. After pre-shearing the sample has kept at rest for 600 seconds prior to measurements in order to permit the material recovering its initial structure partially at least. After kept rest of 600 seconds a continuous ramp of shear stress has been applied. The imposed shear stress range depends on the mass concentration of Poly-sal added in base bentonite (4\%). In this study for the concentration of Poly-sal less than $1 \%$, a continuous ramp of shear stress, which is ranging from 0 to $3.5 \mathrm{~Pa}$ applied during 600 seconds. For the concentrations greater or equal to $1 \%$ a continuous ramp of shear stress, which is ranging from 0 to $4 \mathrm{~Pa}$ applied during 600 seconds.

\subsubsection{Creep-recovery measurements}

Creep and recovery tests are carried out as follows: After a rest time of 600 seconds prior to the measurements, a constant shear stress $\tau=0.5$ was applied to the simples and the compliance $(\mathrm{J})$ was recorded as a function of creep time; at $\mathrm{t}=$ 180 seconds the stress $\tau$ was set to zero and the recoverable part of compliance was measured as a function of the recovery time equal at 180 seconds.

\section{Results and discussion}

\subsection{Effect of Poly-sal on the flow properties of bentonite}

The bentonite dispersions were prepared with $4 \%$ solid content in desalted water and the Poly-sal concentrations ranging between 0 and 1\%. Fig. 2 shows the flow curves of mixtures bentonite $4 \%$ at different concentrations of Poly-sal. Experimental data were fitted to the modified Cross model (Eq. (6)) [28], which has been successfully employed for weak gel systems.

$\tau=\tau_{0}+\eta_{\infty} \dot{\gamma}+\frac{\left(\eta_{0}-\eta_{\infty}\right) \dot{\gamma}}{1+\left(\lambda_{c} \dot{\gamma}\right)^{m}}$

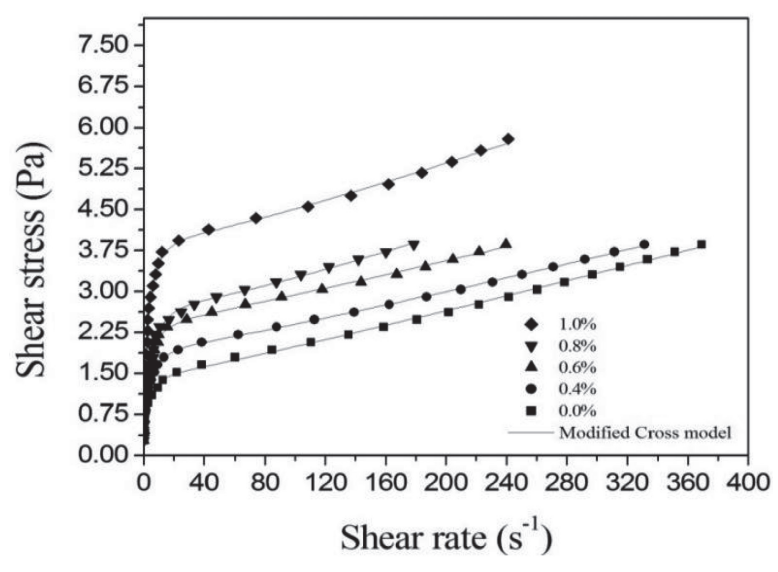

Fig. 2 Shear stress as a function of shear rate at different mass concentrations of Poly-sal add (0, 0.4, 0.6, 0.8 and 1\%) in 4\% of bentonite. The solid lines correspond to the curve fitting to Eq. (6)

2. ábra Nyírófeszülltség a nyírási sebesség függvényében különböző Poly-sal adagolás add (0, 0,4, 0,6, 0,8 és 1\%) mellett $4 \%$ bentonitban. A folytonos vonalak a (6)-os egyenlethez tartoznak

It is clear that the shear stress of the bentonite-Poly-sal systems increased with the increase in the Poly-sal T content. Fig. 3 and 4 shows the variation of the parameters of the modified Cross model for bentonite-Poly-sal mixtures systems as a function of different concentration of Poly-sal added in base bentonite $(4 \%)$ at $20^{\circ} \mathrm{C}$. We observe in Fig. 3 and 4 , a rapid increase in the yield stress, zero shear rate viscosity and the infinite shear rate viscosity with the increase of Polysal concentration, this increase of yield stress, zero shear rate viscosity and the infinite shear rate viscosity is related to the adsorption of Poly-sal by the bentonite. This adsorption makes the specific surface higher and causes an increase of interaction between the bentonite particles. The increase in the yield stress causes an increase in the friction and an increase in the viscosity of the mixture due to the interaction between the solid particles and viscous effects [18]. In this case, the interactions between the clay particles and polymer intensify 
lead to difficult movements in the dispersing medium. In fact, the presence of Poly-sal in the mixture allows reinforcement of the rigidity and the consistency of the mixture because of the structural nature of the Poly-sal.

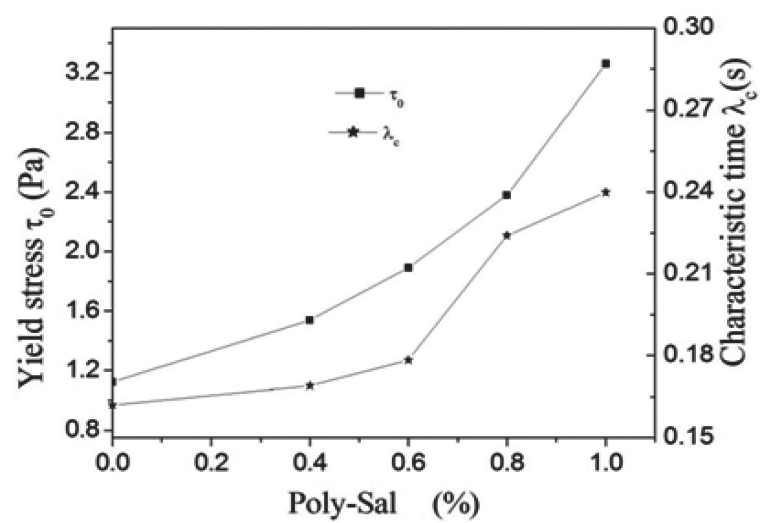

Fig. 3 Variation of yield stress and characteristic time of mixture bentonite base (4\%)-Poly-sal at different concentration of Poly-sal (0, 0.4, 0.6, 0.8 and 1\%)

3. ábra A folyási feszültség és a bentonite(4\%)-Poly-sal keverék karakterisztikus idejének változása - a Poly-sal különböző koncentrációjában (0, 0,4, 0,6, 0,8 és 1\%)

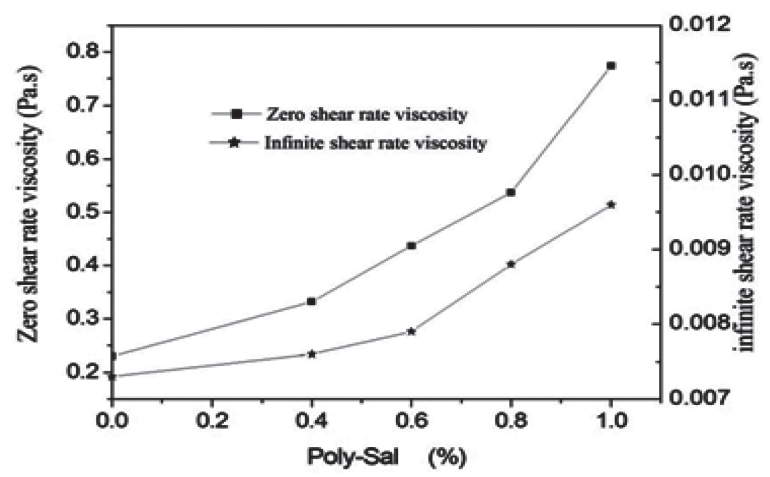

Fig. 4 Variation of zero shear rate viscosity $\eta_{0}$ and the infinite shear rate viscosity $\eta_{\infty}$ of mixture bentonite base (4\%)-Poly-sal at different concentration of Poly-sal $(0,0.4,0.6,0.8$ and $1 \%)$

4. ábra A nulla nyírósebességü viszkozitás valamint a végtelen nyírósebességü viszkozitás a bentonite(4\%)-Poly-sal keverék karakterisztikus idejének függvényében - a Poly-sal különbözö koncentrációjában (0, 0,4, 0,6, 0,8 és $1 \%)$

\subsection{Effect of barite on the viscoelastic properties of bentonite}

After a rest time (time during which the sample is left at rest in geometry) of 600 seconds, in the creep phase, the samples were subjected to constant stress at $0.5 \mathrm{~Pa}$ and at constant temperature $\left(20 \pm 0.2^{\circ} \mathrm{C}\right)$. In the recovery phase, the applied stress was suddenly removed and the sample recovery was registered for an additional period of 180 seconds. Fig. 8 shows the values of compliance $(t)=\frac{\gamma}{\tau}$, as a function of time, for the creep experiments corresponding to the bentonite -barite mixtures studied for ration barite to base bentonite (4\%) range between 0 and 1 , in a time interval between 0 and 180 seconds. For the interval of time between 180 seconds and 360 seconds, we have represented the corresponding recovery. An increase of the elastic compliance (increase of the elastic modulus $\left(G=\frac{1}{3}\right)$ ) with the increase of quantity of barite added in the based bentonite (4\%), indicating an increase of the viscoelastic properties of mixtures barite-bentonite. In other word, the creep deformation decreases with increasing the barite in bentonite and the time necessary to reach a constant deformation during recovery, after removal of the shear stress decreases.

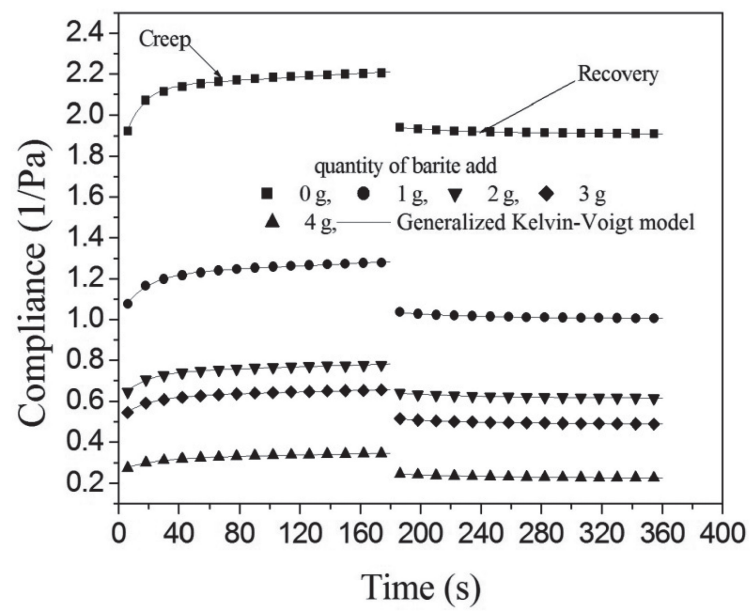

Fig. 5 Compliance versus time in creep and recovery test at different ratio of quantity added in base bentonite $(0,1,2,3$ and $4 \mathrm{~g})$. The solid lines correspond to the curve fitting to Generalized Kelvin-Voigt model

5. ábra A megfelelőség az idő függvényében kúszási és a visszanyerési teszt során a hozzáadott bentonite mennyiségének (0, 1, 2, 3 és $4 \mathrm{~g})$ függvényében. A folytonos vonalak megfelelnek a Generalized Kelvin - Voigt modellhez illeszkedö görbének

The elastic properties were defined by correlating the results with the well-known viscoelastic models of Burger model or Generalized Kelvin-Voigt model [29-30] based on the association in the series of the Maxwell model and the KelvinVoigt model.

The creep curves are described by:

$J_{F}=J_{0}+\frac{t}{\mu_{0}}+\sum_{i=1}^{N} J_{i}\left\lceil-\exp \left(-\frac{t}{\theta_{i}}\right)\right\rceil$

$\theta_{i}=\frac{J_{i}}{\eta_{i}}$

Whereas the recovery strain is given by:

$J_{R}=\frac{t_{1}}{\mu_{0}}+\sum_{i=1}^{N} J_{i}\left[\exp \left(\frac{t_{1}}{\theta_{i}}\right)-1\right] \exp \left(-\frac{t}{\theta_{i}}\right)$

where $J_{0}$ is the purely elastic contribution (or the instantaneous elastic compliance), $\mu_{0}$ is the purely viscous contribution, represented by the despot of the Maxwell model, i.e., the uncoupled or residual steady-state viscosity obtained from the creep curve at long times when the compliance curve is linear, $J_{\mathrm{i}}$ is the contribution to retarded elastic compliance, $\theta_{\mathrm{i}}$ is the retarded time, $\eta_{\mathrm{i}}$ is the retarded viscosity and $t_{1}$ is the time where the stress is applied for $t \leq t_{1}$ and removed at $t=t_{1}$. The fitting parameters are detailed in Table 2. The column $G_{0}=\frac{1}{J_{0}}$ represents the instantaneous elastic modulus of the Maxwell unit at $\mathrm{t}=0$; that is the instantaneous elastic response of the system and the column $G_{1}=\frac{1}{J_{1}}, J_{1}$ is the elastic modulus of Kelvin-Voigt. The latter represents the contributions of the retarded elastic region to the total compliance. The strong increase is observed in $G_{0}$ and $G_{1}$ when the quantity of barite is changed between 0 and $4 \mathrm{~g}$ cause the manifestation of the shift from viscous to elastic behavior and an increase of the viscoelastic properties in that range of barite. 


\begin{tabular}{ccccccc}
\multicolumn{3}{c}{ Creep } & \multicolumn{3}{c}{ Recovery } \\
Barite & $G_{0}(\mathrm{~Pa})$ & $G_{1}(\mathrm{~Pa})$ & $\mu_{0}(\mathrm{~Pa} . \mathrm{s})$ & $G_{1}(\mathrm{~Pa})$ & $\mu_{0}(\mathrm{~Pa} \mathrm{~s})$ & $\theta_{1}(s)$ \\
\hline 0 & 0.56 & 2.88 & 2364.69 & 28.49 & 94.32 & 55.36 \\
\hline 1 & 0.99 & 4.88 & 2872.69 & 29.07 & 179.31 & 56.26 \\
\hline 2 & 1.66 & 7.28 & 3906.40 & 43.48 & 799.49 & 61.12 \\
\hline 3 & 1.95 & 9.43 & 4550.02 & 35.71 & 293.26 & 60.65 \\
\hline 4 & 3.88 & 16.13 & 6899.11 & 34.60 & 369.50 & 59.99 \\
Table 2 & $\begin{array}{l}\text { Fitting parameters of the creep-recovery data in Fig. 5, with N = 1in Eqs. (7) } \\
\text { and (9) } \\
\text { A kúszás-helyreállitási adatok illesztési paraméterei; (7) és (9) egyenletekben } \\
\text { 2. tábla esetén }\end{array}$
\end{tabular}

It has the meaning of viscosity of the system in the Newtonian regime, whereas it also shows a clear increasing trend as the quantity of barite in the based bentonite $(4 \%)$ increases. This increasing of viscosity could be the interactions between bentonite-barite mixture particles and the enhancement of Brownian motion. At high quantity of barite added in based bentonite, the applied stress of $0.5 \mathrm{~Pa}$ is not sufficient to break particle-to-particle bonds, and the mixtures (Bentonite-Barite) do not flow. For lower quantity of barite values such resistance to flow is not so large, and this explains the values of and in this case the retarded deformation, related to the breaking and reconstruction of weak links between the particles. The characteristic relaxation time associated with these breaking/ reconstruction processes is. Although this time does not show a definite trend when estimated from creep data.

\subsection{Apparent viscosity evolution under constant shear rate and determination of the structural parameter of mixtures barite-bentonite}

Figs. 6 and 7 show the time dependence of apparent viscosity for constant shear rates $\left(0.5 \mathrm{~s}^{-1}\right.$ and $\left.0.8 \mathrm{~s}^{-1}\right)$ at different quantities of barite $(0,1,2,3$ and $4 \mathrm{~g})$ added in base bentonite (4\%) fitted with the second-order SKM (see Eq. (5)).

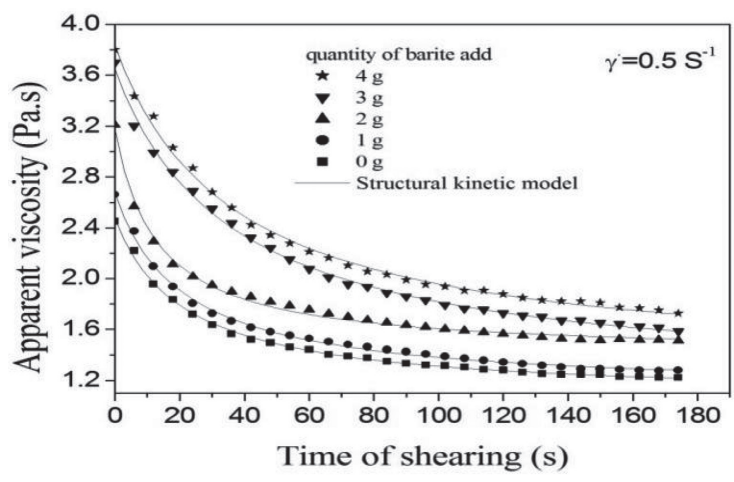

Fig. 6 Apparent viscosity data of barite-bentonite mixtures as a function of shearing time at $20^{\circ} \mathrm{C}$ for different quantities of barite added in bentonite (4\%) and for constant shear $0.5 s-1$. The solid line corresponds to curve fitting to Eq. (5) where $n=2$

6. ábra A barit-bentonit keverékek látszólagos viszkozitási adatai a nyírási idô függvényében $20^{\circ} \mathrm{C}$-on különbözö mennyiségü barit esetén, 4\%-os bentonite adagolás és állandó nyírási sebesség $(0,5 s-1)$ mellet. A folytonos vonal megfelel az (5)-ös egyenletre illeszkedő görbének $n=2$ esetén

A good concordance was found between the model fitted results (solid line) and the experimental transient apparent viscosity data for all quantities of barite added in base bentonite $(4 \%)$ and for the both shear rates applied.

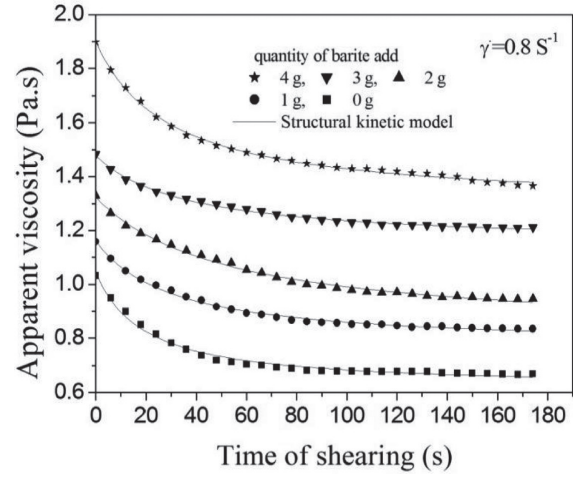

Fig. 7 Apparent viscosity data of barite-bentonite mixtures as a function of shearing time at $20^{\circ} \mathrm{C}$ for different quantities of barite added in bentonite (4\%) and for constant shear $0.8 s^{-1}$. The solid line corresponds to curve fitting to Eq. (5) where $n=2$

7. ábra A barit-bentonit keverékek látszólagos viszkozitási adatai a nyírási idó függvényében $20^{\circ} \mathrm{C}$-on különböző mennyiségü barit esetén, 4\%-os bentonite adagolás és állandó nyírási sebesség $\left(0,8 \mathrm{~s}^{-1}\right)$ mellet. A folytonos vonal megfelel az (5)-ös egyenletre illeszkedö görbének $n=2$ esetén

For all studied quantities of barite added in base bentonite and for both shear rates, the viscosity decreases significantly with shearing time, particularly in the initial stages of shearing. After approximately 140 seconds shearing periods for shear rate of $0.5 \mathrm{~s}^{-1}$ applied on the mixtures and after approximately 100 seconds of shearing periods for shear rate of $0.8 \mathrm{~s}^{-1}$ applied in the mixtures, the viscosity tends to an equilibrium value. Therefore the equilibrium state of mixtures barite-bentonite depends on the shear rate applied to the system. Fig. 8 shown the variation of the rate constant $\mathrm{k}$ and the equilibrium structural parameter $\lambda_{\mathrm{e}}$ as a function of the quantity of barite added in base bentonite (4\%) and for both shear rates applied.

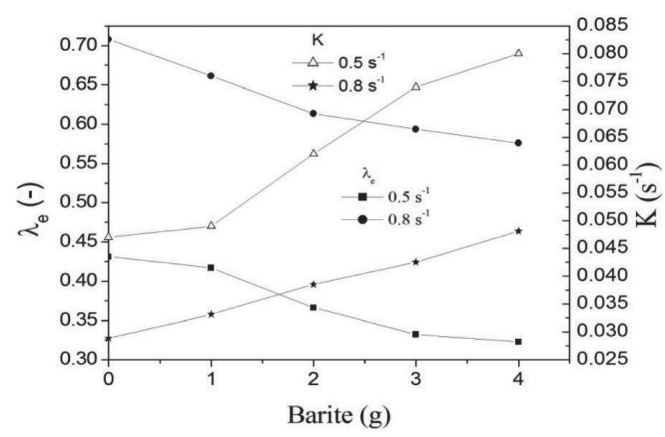

Fig. 8 the variation of the rate constant $k$ and equilibrium structural parameter as a function of the quantity of barite added in base bentonite (4\%) and for both shear rates applied

8. ábra A k sebességi állandó és az egyensúlyi szerkezeti parameter változása a barit mennyiségének (4\%) függvényében, mindkét alkalmazott nyírási sebesség esetén

The rate $k$ constant $\mathrm{k}$ can be considered as a measure of the rate of the structural breakdown, i.e. the degree of thixotropy. On the other hand, the ratio of equilibrium to initial viscosity can be considered as an equilibrium structural parameter $\lambda_{e}=\frac{\eta}{\eta}$. We observed in Fig. 6 an increase of the degree of thixotropy with increase of the quantity of barite in bentonite. This increase in the degree of thixotropy leads to an increase in the yield stress and the apparent viscosity of the mixtures bentonite-barite.

As it is shown in Fig. 9 structural parameter changes are most significant during the initial shear period after which nearly constant values are reached. 


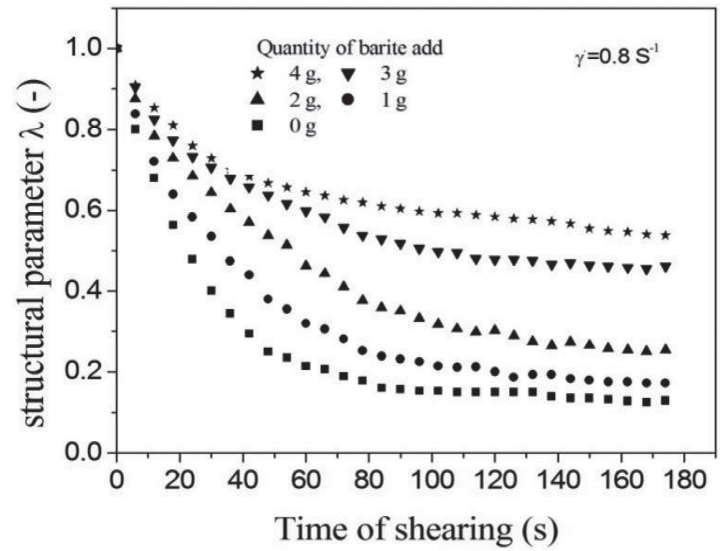

Fig. 9 Structural parameter as a function of time at $20^{\circ} \mathrm{C}$ for different quantities of barite adds in bentonite for shear rate of $0.8 \mathrm{~s}^{-1}$

9. ábra A szerkezeti parameter a nyírási idö függvényében, $20^{\circ} \mathrm{C}$-on, különböző barit adagolás mellett 0,8 $\mathrm{s}^{-1}$-es nyírási sebesség mellett

We also find that the structural parameter of mixture suspension (bentonite-barite) increases with increasing the quantity of barite added in bentonite. This behavior could be explained by the deflocculating of mixtures particles in the water at high quantity of barite added $(4 \mathrm{~g})$. The applied stress of $0.8 \mathrm{~s}^{-1}$ is not sufficient to break particle-to-particle bonds. The mixture in this case developed a network structure which leads to enhance the organization of particles in the mixtures at the microstructural level [31].

\section{Conclusions}

The effect of Poly-sal polymer on the stationary behavior of bentonite and the effect of barite on the viscoelastic and thixotropic behavior of bentonite were studied. The stationary flow curves of bentonite at different concentration of Poly-sal add in base bentonite (4\%) was successfully modeled using The Modified Cross model. the generalized model of Kelvin-Voigt is successfully applied to fit the creep and recovery data and to analyze the viscoelastic properties of mixture bentonite-barite.

The addition of Poly-sal in a concentration range between 0 and $1 \%$ to $4 \%$ of bentonite leads to an increase in the yield stress $\tau_{0}$, zero shear rate viscosity $\eta_{0}$ and the infinite shear rate viscosity $\eta_{\infty}$ with dose of Poly-sal. The increase of these parameters is related to the interaction between the solid particles and the viscous effects. The increase of the modified Cross model parameters causes an increase in the friction and an increase in the viscosity of the mixture.

The increase of quantity of barite in bentonite suspensions causes an increase of the viscoelastic behavior of the system and the structure of particle-to-particle bonds. in order to avoid the problems related to the structure of particle-to-particle bonds of bentonite, caused by high concentration of barite, during the process of pumping, we propose the addition of an electrolyte as a third additive i.e., bentonite-barite- electrolyte. The effect of barite on the break-down behavior of the bentonite suspension was examined. The time dependent viscosity decreased rapidly with shearing time and reached a steady state. The structural kinetic model (SKM) for viscosity decay with time at the constant shear rate was applied successfully to analyze the time-dependent behavior of bentonite-barite mixtures. The rate of structure breakdown (degree of thixotropy) increases with increasing quantity of barite added to based bentonite.

\section{References}

[1] Vryzas, Z. - Kelessidis, VC. - Nalbantian, L. - Zaspalis, V. Gerogiorgis, DI. - Wubulikasimu, Y. (2017): Effect of temperature on the rheological properties of neat aqueous Wyoming sodium bentonite dispersions. Applied Clay Science, Vol. 136, pp. 26-36, ISSN: 0169-1317, https://doi.org/10.1016/j.clay.2016.11.007.

[2] Y., Ren et al., (2019): Adsorption of imidazolium-based ionic liquid on sodium bentonite and its effects on rheological and swelling behaviors. Applied Clay Science, Vol. 182, pp. 105248, ISSN: 0169-1317, https://doi.org/10.1016/j.clay.2019.105248.

[3] Mellak, Abderrahmane (2019): Mathematical modelling: case of Haoud Berkaoui. Epitoanyag-Journal of Silicate Based \& Composite Materials, Vol. 71, No. 1.

[4] Kok, MV. (2011): A rheological characterization and parametric analysis of a bentonite sample. Energy Sources, Part A: Recovery, Utilization and Environmental Effects. 33(4): 344-348.

[5] Ișçi, E. - Turutoğlu, S. İ. (2011): Stabilization of the mixture of bentonite and sepiolite as a water based drilling fluid. Journal of Petroleum Science and Engineering, Vol. 76, Issues: 1-2, pp. 1-5, ISSN 0920-4105. https://doi.org/10.1016/j.petrol.2010.11.021.

[6] Coussot, P. - Tabuteau, H. - Château, X. - Tocquer, L. - Ovarlez, G. (2006): Aging and solid or liquid behavior in pastes. Journal of Rheology. Vol. 50, pp. 975- 94, https://doi.org/10.1122/1.2337259.

[7] Lam, C. - Jefferis, S. A. - Suckling, T. P. - Troughton, V. M., (2015): Effects of polymer and bentonite support fluids on the performance of bored piles. Soils and Foundations, Vol. 55, Issue 6, pp. 1487-1500, ISSN 00380806, https://doi.org/10.1016/j.sandf.2015.10.013.

[8] Besq, A. - Malfoy, C. - Pantet, A. - Monnet, P. - Righi, D. (2003): Physicochemical characterisation and flow properties of some bentonite muds. Applied Clay Science, Vol. 23, Issues 5-6, pp. 275-286, ISSN 01691317, https://doi.org/10.1016/S0169-1317(03)00127-3.

[9] Hempoonsert, J. - Tansel, B. - Laha, S. (2010): Effect of temperature and $\mathrm{pH}$ on droplet aggregation and phase separation characteristics of flocs formed in oil-water emulsions after coagulation. Colloids and Surfaces A: Physicochemical and Engineering Aspects. Vol. 353, Issue 1, pp. 37-42, ISSN 0927-7757, https://doi.org/10.1016/j.colsurfa.2009.10.016.

[10] Abend, S. - Bonnke, N. - Gutschner, U. - Lagaly, G. (1998): Stabilization of emulsions by heterocoagulation of clay minerals and layered double hydroxides. Colloid \& Polymer Science. Vol. 276, pp. 730-737, https://doi.org/10.1007/s003960050303.

[11] Abderrahmane, Mellak (2007): Caracterisations rhéologiques des coulis de ciments spécifiques aux formations salifères.Lebanese Science Journal, Vol. 8, No (2), pp.115-125.

[12] Barast, G. - Razakamanantsoa, A. R. - Djeran-Maigre, I. - Nicholson, T. - Williams, D. (2016): Swelling properties of natural and modified bentonites by rheological description. Applied Clay Science, Vol. 142, pp. 60-68, ISSN 0169-1317, https://doi.org/10.1016/j.clay.2016.01.008.

[13] Abu-Jdayil, B. - Ghannam, M. (2014): The modification of rheological properties of sodium bentonite-water dispersions with low viscosity CMC polymer effect. Energy Sources, Part A: Recovery, Utilization, and Environmental Effects. Vol. 36, pp. 1037-1048,

[14] Menezes, R. R. - Marques, L. N. - Campos, L. A. - Ferreira, H. S. - Santana, L. N. L. - Neves, G. A., (2010): Use of statistical design to study the influence of CMC on the rheological properties of bentonite dispersions for water-based drilling fluids. Applied Clay Science. Vol. 49, Issues 1-2, pp. 13-20, ISSN 0169-1317, https://doi.org/10.1016/j.clay.2010.03.013.

[15] Yap, J. - Leong, Y. K. - Liu, J. (2011): Structural recovery behavior of barite-loaded bentonite drilling muds. Journal of Petroleum Science and Engineering. Vol. 78, Issue 2, pp. 552-558, ISSN 0920-4105, https://doi.org/10.1016/j.petrol.2011.06.010.

[16] Asghari, I. - Esmaeilzadeh, F. (2013): Manipulation of key parameters in RESS process for attapulgite particles utilizing in drilling mud and investigation on its rheological characteristics. Journal of Petroleum 
Science and Engineering. Vol. 112, pp. 359-369, ISSN 0920-4105, https://doi.org/10.1016/j.petrol.2013.09.013.

[17] Benchabane, A. - Bekkour, K., 2006: Effects of anionic additives on the rheological behavior of aqueous calcium montmorillonite suspensions. Rheologica Acta. Vol. 45, No (4), pp. 425-434,

https://doi.org/10.1007/s00397-005-0063-1

[18] Hammadi, L. - Boudjenane, N. - Belhadri, M. (2014): Effect of polyethylene oxide (PEO) and shear rate on rheological properties of bentonite clay. Applied Clay Science. Vol. 99, pp. 306-311, ISSN: 01691317, https://doi.org/10.1016/j.clay.2014.07.016.

[19] Azouz, K. B. - Bekkour, K. - D., Dupuis (2016): Influence of the temperature on the rheological properties of bentonite suspensions in aqueous polymer solutions. Applied Clay Science. Vol. 123, pp. 92-98, ISSN: 0169-1317, https://doi.org/10.1016/j.clay.2016.01.016.

[20] Ouaer, H. - Gareche, M. (2019): Hydroxyethyl cellulose as a rheology modifier for water-based drilling fluids formulated with Algerian bentonite. Journal of the Brazilian Society of Mechanical Sciences and Engineering Vol. 41:123, https://doi.org/10.1007/s40430-019-1627-9

[21] Abdou, M. I. - Al-Sabagh, A. M. - Ahmed, Hany El-Sayed - Fadl, A. M. (2018): Impact of barite and ilmenite mixture on enhancing the drilling mud weight. Egyptian Journal of Petroleum, Vol. 27, Issue 4, pp. 955-967, ISSN: 1110-0621, https://doi.org/10.1016/j.ejpe.2018.02.004.

[22] Benyounes, K. - Mellak, A. - Benchabane, A. (2010): The effect of carboxymethylcellulose and xanthan on the rheology of bentonite suspensions. Energy Sources, Part A: Recovery, Utilization, and Environmental Effects. Vol. 32, pp. 1634-1643.

[23] Kelessidis, V. C. - Poulakakis, E. - Chatzistamou, V. (2011) : Use of Carbopol 980 and carboxymethyl cellulose polymers as rheology modifiers of sodium-bentonite water dispersions. Applied clay science, Applied Clay Science, Vol. 54, Issue 1, pp. 63-69, ISSN: 0169-1317, https://doi.org/10.1016/j.clay.2011.07.013.

[24] Shaikh, S. M. - Nasser, M. S. - Hussein, I. - Benamor, A. - Onaizi, S. A. - Qiblawey, H. (2017): Influence of Polyelectrolytes and Other Polymer Complexes on the Flocculation and Rheological Behaviors of Clay Minerals: A Comprehensive Review. Separation and Purification Technology. Separation and Purification Technology, Vol. 187, pp. 137161, ISSN: 1383-5866, https://doi.org/10.1016/j.seppur.2017.06.050.
[25] Benslimane, A. - Bahlouli, I. M. - Bekkour, K. - Hammiche, D. (2016): Thermal gelation properties of carboxymethyl cellulose and bentonitecarboxymethyl cellulose dispersions: Rheological considerations, Applied Clay Science, Vol. 132-133, pp. 702-710, ISSN: 0169-1317, https://doi.org/10.1016/j.clay.2016.08.026.

[26] Nguyen, Q. D. - Jensen, C. T. - Kristensen, P. G. (1998): Experimental and modelling studies of the flow properties of maize and waxy maize starch pastes. Chemical Engineering Journal. Vol. 70, Issue 2, pp. 165-171, ISSN: 1385-8947, https://doi.org/10.1016/S0923-0467(98)00081-5.

[27] Abu-Jdayil, B. (2003): Modelling the time-dependent rheological behavior of semisolid foodstuffs. Journal of food engineering. Vol. 57, pp. 97-102, ISSN: 0260-8774, https://doi.org/10.1016/S0260-8774(02)00277-7.

[28] Grassi, M. - Lapasin, R. - Pricl, S. (1996): A study of the rheological behavior of scleroglucan weak gel systems. Carbohydrate Polymers, Vol 29, Issue 2, pp. 169-181, ISSN: 0144-8617, https://doi.org/10.1016/0144-8617(95)00120-4.

[29] Hammadi, L. - Ponton, A. (2017): Rheological Investigation of Vase of Dam: Effects of Aging Time, Shear Rate, and Temperature. Applied Rheology. Vol. 27, No 1, pp. 21-29.

[30] Dolz, M. - Hernández, M. J. - Delegido, J. (2008): Creep and recovery experimental investigation of low oil content food emulsions. Food Hydrocolloids. Vol. 22, pp. 421-427.

[31] Wang, Q. - Cui,Y.J - Tang, A. M. - Barnichon, J. D. - Saba, S. - Ye, W. M (2013): Hydraulic conductivity and microstructure changes of compacted bentonite/sand mixture during hydration. Engineering Geology vol. 164, pp. 67-76.

Ref:

Bachir Belmehdi, Ilyes - Mellak, Abderrahmane - Hammadi, Larbi: Effects of poly-sal polymer and barite addition on rheological properties of algerian bentonite

Építőanyag - Journal of Silicate Based and Composite Materials, Vol. 73, No. 1 (2021), 2-8. p. https://doi.org/10.14382/epitoanyag-jsbcm.2021.1

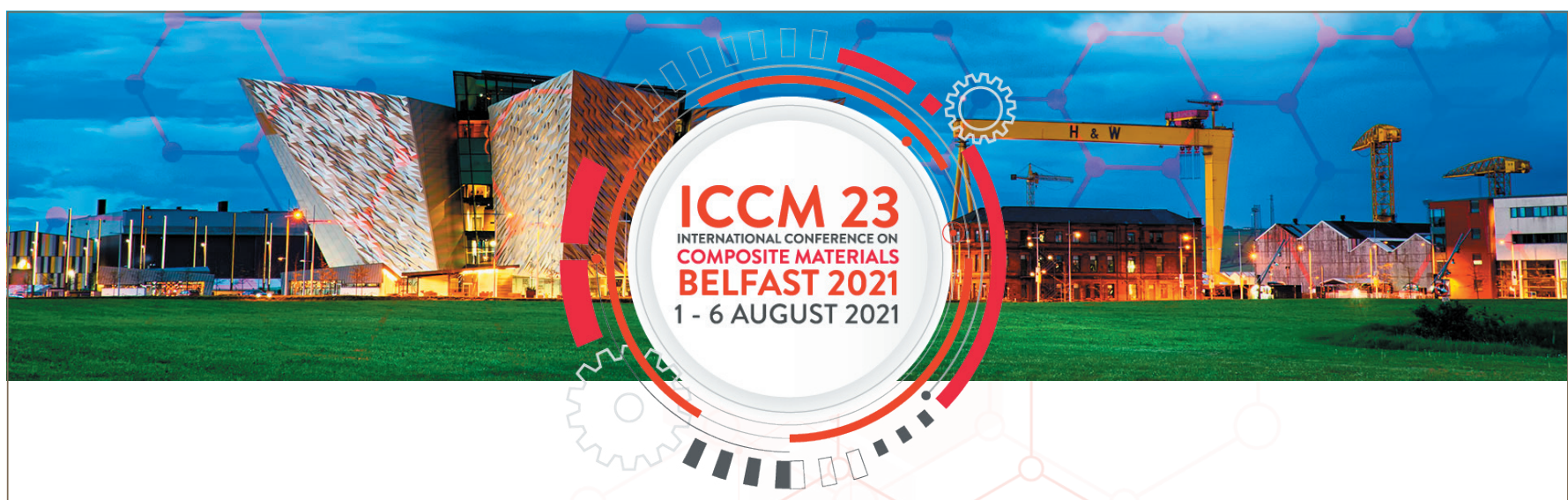

The 23rd International Conference on Composites Materials (ICCM 23) will be held in Belfast, Northern Ireland, from the 1st to 6th of August 2021. ICCM is the premier international conference in the field of composite materials and was first held in 1975 in the cities of Geneva and Boston. Since that time the conference has been held biennially in North American, European, Asian, Oceanic, and African cities.

ICCM 23 will attract the leading researchers and practitioners, to report and exchange ideas on the latest developments in the advancement and exploitation of a wide range of composites materials and structures. The general themes of material development, testing, modelling, manufacturing and design will encompass a breadth of topics which will provide a comprehensive global snap-shot of the state-of-the-art.

Plenary and keynote lectures from pre-eminent leaders in the field are planned, along with oral and poster presentations from an expected large delegation coming together in Belfast from all corners of the world. A number of site visits and an entertaining social programme are also planned.

\section{iccm23.org}

